\title{
EXPERT RESEARCH ON QUALITY DETERMINATION OF ENTRANCE METAL DOORS
}

\section{Matsak N. A., Kyrylenko S. A., Posashkov O. O.}

The article outlines the mandatory quality requirements for manufactured and installed metal entrance shockproof doors, which should ensure the safety of life, health and property of citizens. The main technical features of these designs and their characteristics are presented. The problem of quality control is considered, since quality is a guarantee of reliability and operating life. The installation of high-quality "armored" doors will not only protect housing from unauthorized penetration, but also help to isolate the premise from the external environment; therefore in the problem of selecting entrance metal doors, an important place is occupied by the issue of heat and sound insulation. While choosing a good metal door, every detail should be taken into account. The quality of the goods and safety of the premise directly depend on all design components. The article raises such a topical issue as the establishment of quality works on manufacture, storage, transportation and mounting of entrance metal shockproof doors while performing forensic construction and technical examination. The technical characteristics of building materials that can be used in this case are presented. The authors also pointed out that it is very important to resolve disputes on this type of researches, so this is the availability of technical documentation. All data about the product should be included in this documentation up to the information on transportation and storage, since this information will much facilitate the work of experts in the future. After all, the establishment of the quality of this type of products is a fairly complex and time-consuming process. While determining the quality, all details are important, starting from the quality of the used building materials, the works on manufacturing of the door blocks, their storage and transportation conditions, and finishing the placing (mounting).

Keywords: door block, high-strength doors, quality, armored structures, operational loads, technical documentation, sealing gaskets, locks, security of premise.

DOI: https://doi.org/10.32353/khrife.2018.49

УДК 343.148:656.21

о. В. Джус, завідувач лабораторії Львівського НДІСЕ

E-mail: DjusOV22@gmail.com

\section{МЕТОДОЛОГІЧНІ ПІДХОДИ ДО ПРОВЕДЕННЯ СЛУЖБОВОГО РОЗСЛІДУВАННЯ ЗАЛІЗНИЧНОЇ ПРИГОДИ В УКРАЇНІ ТА ЗА КОРДОНОМ}

Проаналізовано методологічні підходи до службового розслідування залізничних пригод в Україні та за кордоном, результати яких досліджуються експертом при виконанні судових залізнично-транспортних експертиз.

Ключові слова: залізнично-транспортна пригода, катастрофа, аварія, безпека руху, службове розслідування, залізнично-транспортна експертиза.

При наданні послуг із перевезення пасажирів і вантажу завжди присутній ризик появи нестандартної ситуації внаслідок впливу різноманітних чинників чи дій людей (операторів) - залізнично-транспортної пригоди

(C) Джус О. В., 2018 
(далі - ЗТП $)^{1}$. При виникненні такої ситуації в Україні проводиться службове розслідування - установлюються причини настання ЗТП. Матеріали, свідчення й факти, що встановлюються при такому виді розслідувань, $\epsilon$ досить важливими та використовуються при проведенні дослідження в межах виконання залізнично-транспортної експертизи.

Усі методи дослідження причин і факторів впливу на виникнення ЗТП зводяться до однієї мети - підвищення якості її розслідування. Результати таких службових (спеціальних) розслідувань використовуються експертами при виконанні судових залізнично-транспортних експертиз.

У різних країнах по-різному мають назву документи, які регламентують порядок проведення службового (спеціального) розслідування (далі - с. р.). Саме для дослідження підходів до проведення с. р. в Україні та за кордоном слід розглянути ці документи. У країнах СНД, Балтії та в Україні випадки, коли в процесі розслідування не виявляються, не фіксуються, не реєструються всі чинники, у тому числі й досить важливі, що впливають на процес взаємодії колії та рухомого складу. Визначення ж самих причин проводиться недостатньо обгрунтовано, а в окремих випадках - невірно. У переважному числі матеріалів с. р. відсутні найважливіші чинники, що визначають джерела підвищення силових впливів рухомого складу на колію, які призводять до його сходження з рейок. У ряді випадків при виконанні судових залізнично-транспортних експертиз виявляється «чисто відомчий підхід» керівників до розслідування, що виражається в перекручуванні реальних обставин сходження. Мали місце випадки приховування зацікавленими особами фактичних даних про стан екіпажної частини рухомого складу, швидкості та режимів руху поїзда, найважливіших слідів на колії та рухомому складі. Украй негативно на повноті і якості проведення с. р. позначається недостатня підготовка й знання деяких працівників основ взаємодії колії та рухомого складу, невміння й небажання виконувати необхідні в кожному конкретному випадку відповідні розрахунки. Невірно визначені обставини та причини ЗТП негативно позначаються на ефективності розроблених заходів щодо попередження подібних випадків у майбутньому.

1 Сокол Э. Н. Крушения железнодорожных поездов (Судебная экспертиза. Элементы теории и практики) : монография. Киев : Феникс, 2009. 376 с.; Його ж. Сходы с рельсов и столкновения подвижного состава (Судебная экспертиза. Элементы теории и практики). Киев : Транспорт України, 2004. 368 с.

2 Кудрявцев М. Н. Крушения и аварии на железнодорожном транспорте и борьба с ними. Киев : Гос. науч.-техн. изд-во Украины, 1935. 109 с.; Directive 2004/49/EC of the European Parliament and of the Council of 29 April 2004. Official Journal of the European Union. L-series. 30.04.2004. Рp. 44-113; Лапін П. В. Класифікація залізничних транспортних подій за критерієм економічних збитків. Ефективна економіка. 2005. № 5; Нормативні акти з безпеки руху поїздів / В. Зайцев, А. Рашко, В. Крот, М. Ришковський. Київ : Транспорт України, 2002. 142 с.; Инструкция о порядке совместных действий железнодорожных администраций государств-участников Содружества Независимых Государств, Латвийской Республики, Литовской Республики, Эстонской Республики по служебному расследованию нарушений безопасности движения в поездной и маневровой работе от 22 мая 2009 г. URL: http:// zakon4.rada.gov.ua/laws/show/998_413. 
Після отримання інформації про виникнення ЗТП на залізницях створюється комісія для проведення службового розслідування й установлення причин іiї настання. До складу комісій залучаються фахівці господарств із високим рівнем знань і значним досвідом роботи. До складу комісій, як правило, не включають працівників, з вини яких сталася ЗТП. У структурних підрозділах, службах можуть бути створені постійно діючі комісії. Керівники господарств повинні вживати заходів щодо підготовки фахівців для участі в роботі цих комісій. На залізницях з ними необхідно проводити періодичні семінари з обміну досвідом щодо збирання та оброблення інформації, проведення розрахунків, визначення причин ЗТП і оформлення матеріалів с.р. Усі члени комісії повинні вміти користуватися вимірювальними приладами для вимірювання параметрів колії, рухомого складу, знати норми та допустимі відступи від цих параметрів.

До складу комісій необхідно залучати ревізорів з безпеки руху поїздів залізниць і дільниць залізниць, які повинні здійснювати контроль за якістю с. p. та достовірністю інформації, яка надається для його проведення. Кожен член комісії несе персональну відповідальність за достовірність інформації, наданої ним для визначення причини ЗТП. При розслідуванні ЗТП члени комісії в обов'язковому порядку з'ясовують технічні, організаційні та психофізіологічні (людські) причини. Комісія повинна зібрати максимальну кількість інформації (параметри колії, рухомого складу, дії причетних працівників) навіть у тих випадках, коли причина сходу цілком очевидна. При визначенні причин ЗТП комісія, крім вимог нормативно-правових актів, може для проведення розрахунків використовувати інші джерела (технічну літературу, наукові статті з результатами досліджень і висновків, а також іншу інформацію, яка сприяє встановленню причин).

У разі незрозумілого, неповного трактування необхідних норм чинних нормативно-правових актів, а також незрозумілого їх визначення голова комісії може звернутися до розробника цих документів для надання ним необхідних роз'яснень і коментарів.

Головним завданням комісії згідно з існуючими методами проведення службового розслідування на початковій стадії є найбільш необхідним збирання повною мірою достовірних даних про стан колії, рухомого складу та іншої інформації, яка має відношення до пригоди. Без цього в багатьох випадках причину настання пригоди (сходу) визначити буде неможливо навіть комісіям незалежних експертів. Для визначення необхідних параметрів вагонів, локомотивів, що зійшли з рейок, необхідно залучати фахівців колійного господарства, а для огляду та вимірювання параметрів колії, навпаки, залучати фахівців вагонного та локомотивного господарств із відображенням виміряних параметрів в актах із підписами цих фахівців.

Методологічні підходи при проведенні службового розслідування ЗТП в Україні. Розглянемо історію виникнення та розвитку нормативної бази для проведення службового розслідування ЗТП. На різних етапах формування сучасної системи службових розслідувань видавалися такі нормативні документи: 
— Інструкція з службового розслідування, обліку пожеж та наслідків від них на залізничному транспорті: наказ Міністерства транспорту України від 05.01.1995 № 8;

- Інструкція про порядок службового розслідування транспортних подій та порушень безпеки руху на залізницях України: наказ Міністерства транспорту України від 21.07.2003 № 548;

- Методичні вказівки щодо порядку службового розслідування причин сходжень рухомого складу з рейок на залізницях України: наказ Укрзалізниці від 21.06.2012 № 194-ЦЗ (далі - Методичні вказівки).

- Тимчасовий порядок службового розслідування транспортних подій у публічному акціонерному товаристві «Українська залізниця», який діє 31 січня 2018 р. (далі - Тимчасовий порядок).

Інструкція з службового розслідування, обліку пожеж та наслідків від них на залізничному транспорті більше стосувалася такого явища, як пожежа на залізничному транспорті. Ця Інструкція була недостатньою при виконанні службового розслідування транспортних подій.

Інструкція про порядок службового розслідування транспортних подій та порушень безпеки руху на залізницях України, у якій наведено тлумачення поняття службового розслідування, список осіб, що включаються в комісію із розслідування, їх дії та порядок оформлення висновку, також потребувала доопрацювань і доповнень. На заміну цій Інструкції з 1 січня 2018 р. прийнято в дію Тимчасовий порядок. Він установлює порядок організації, проведення розслідування, оформлення матеріалів службового розслідування транспортних подій і контролю за усуненням недоліків, що призвели до ЗТП.

Зазначені Інструкції в дуже стислій формі розкривали поняття службового розслідування та узагальнювали порядок оформлення його результатів, але не розкривали всі необхідні моменти при розслідувані, хоча $є$ фундаментальною основою нормативної бази при їх проведенні. Вони стали основою для створення чинних на сьогодні Методичних вказівок щодо порядку службового розслідування причин сходу рухомого складу з рейок на залізницях України.

Методичні вказівки забезпечують певну чіткість і послідовність дій при здійсненні с. p. Цей документ установлює (регламентує) порядок організації, проведення с. p., перелік інформації для першочергового одержання: про технічний стан рухомого складу, колії, різноманітні дані, які надаються керівниками служб комісії, про проведення службових експериментів, види й механізми сходу коліс з рейок, про причини сходу рухомого складу з рейок, положення з визначення причин сходу рухомого складу (на кривих ділянках колії, за даними швидкостемірної стрічки та ін.), про сліди сходу, види сходу рухомого складу, про роботу автогальм і правил їх застосування, про розміщення вантажів у вагонах, про причини зростання поздовжніх стискаючих сил у поїзді, груповий боковий вплив на рейки коліс справного візка та інші необхідні для проведення повного, наскільки це можливо, незалежного с. p.

Надана інформація щодо ЗТП систематизується й обробляється, починаючи з повідомлення про ії̈ виникнення. Комісія з розслідування, прибувши 
на місце ЗТП (сходу, зіткнення, наїзду тощо), проводить огляд і обстеження стану залізничної колії, рухомого складу та місця події. При цьому комісія впевнюється у відсутності зламів рейок, деталей рухомого складу, падіння деталей рухомого складу на колію, порушення кріплення й розвалювання вантажу, накладення сторонніх предметів на колію, навмисних дій, спрямованих на пошкодження колії, рухомого складу, споруд і пристроїв залізниці тощо.

Службове розслідування починається з аналізу режиму ведення машиністом поїзда по дільниці і відповідність його руху встановленій режимній карті та іншим нормативним документам. Для цього на місці сходу вилучають: швидкостемірну стрічку локомотива; довідку про наявність і стан гальм поїзда, форма ВУ-45; натурний лист поїзда, форма ДУ-1; перевізні документи на вантаж у вагонах, що зійшли з рейок; бланк попередження про обмеження швидкості руху; маршрутний лист машиніста; журнал технічного огляду локомотива або МВРС, форма ТУ-152.

Також комісією з розслідування ЗТП виконуються такі основні дії, як:

1. За натурним листом визначається кількість одиниць рухомого складу, що зійшли з рейок, рід вантажу та кількість вантажу у вагонах, небезпечність цього вантажу для людей і довкілля.

2. Складається інформаційне повідомлення про ЗТП, зазначається дата, час пригоди, короткий іiі опис, кількість утраченого вантажу, кількість загиблих чи травмованих осіб, забруднення довкілля (якщо таке мало місце). Для уникнення викривлення інформації про обставини ЗТП у засобах масової інформації інформаційне повідомлення за рішенням голови комісії надається представникам влади, працівникам правоохоронних органів, МНС, засобам масової інформації, які можуть прибути на місце події.

3. Перевіряється положення стрілочних переводів, стан світлофорів (технічний стан, показання світлофора), сигналів і сигнальних знаків. 3'ясовується, чи не було свідків під час сходу вагонів з рейок.

4. Фіксується на рейках місце зупинки першої колісної пари локомотива поїзда та окремих груп вагонів. Складається масштабна схема зруйнованої ділянки колії, розташування повалених вагонів і колісних пар вагонів, що зійшли з рейок, із нанесенням відстаней між ними в метрах із прив'язкою до кілометрових стовпчиків або пікетів.

Особливо важливим є факт фіксації місця, де зупинився локомотив. Відмітку на рейках про місце зупинки першої колісної пари локомотива наносить машиніст або його помічник. Якщо до моменту приїзду комісії локомотив був відчеплений від складу поїзда один або з групою вагонів без такої відмітки, його початкове положення на колії відновлюється, виходячи з розташування групи вагонів, що залишилася, і довжини відчепленої групи. Усі ці моменти повинні бути зафіксовані актом і схемою, що відображає положення локомотива, відчепленої групи вагонів і групи вагонів, яка залишилась на час прибуття комісії.

5. Одним із найважливіших і першочергових завдань комісії є складання детальної схеми розташування екіпажів, що зійшли і не зійшли з рейок, 
3 прив'язкою до пікетажу із зазначенням розташування переднього та заднього візків (у разі, коли при сході вагони розвертаються на $180^{\circ}$ ). Якщо візки відділені від вагона, їх розташування також необхідно зафіксувати. Якщо від вагонів відділені колісні пари, то їх також необхідно зафіксувати iз зазначенням номера колісної пари у вагоні за напрямком руху, а також зазначити ліва чи права сторони руху.

Точність вимірювання відстаней між вагонами, що зійшли і не зійшли 3 рейок, допускається в межах 1 м. На вагонах, що зійшли, фіксуються номери (за трафаретами на кузовах) і місце знаходження найближчого світлофора. Особливу важливість для визначення причини сходу є позначення на схемі, у який бік за ходом поїзда зійшли колеса візків, що частково залишилися на рейках, із прив'язкою до пікетажу.

6. Установлюється місце (початок) сходу коліс вагонів з рейок, проставляються відмітки цих місць на шийках обох рейок вертикальними лініями. Складається схема цих слідів на рейках із нанесенням розмірів.

7. Складаються акти огляду головної та хвостової частини поїзда, що не сходили з рейок із зазначенням увімкнення автогальм і положенням режимів у повітророзподільниках.

8. Фіксуються погодні умови у момент сходу вагонів з рейок: напрям руху вітру відносно до напрямку руху поїзда; наявність опадів (сніг, дощ, туман, суха погода).

9. Збираються пояснення від причетних осіб або свідків, які можуть бути використані для встановлення причин сходу.

10. На місці сходу необхідно виконати фотографування. При фотографуванні деталей локомотивів, вагонів, елементів колії, схем розміщення вантажу у вагонах необхідно прикладати лінійку чи іншим способом дати зрозуміти про масштаб. Фотографії повинні пояснювати причину сходу. При долученні до матеріалів с. р. на них необхідно робити пояснювальні надписи. У разі проведення відеозйомки необхідне обов'язкове голосове супроводження з детальним поясненням знятого відеоматеріалу.

11. Отримуються від машиніста й помічника машиніста письмові пояснення, у яких вони повинні надати конкретні відповіді на такі питання:

- положення контролера, якщо поїзд прямував у режимі тяги;

— якщо поїзд прямував у режимі гальмування, то яким чином виконувалось гальмування - краном машиніста, краном допоміжного гальма локомотива, застосуванням рекуперативного гальмування, із подаванням чи без подавання піску;

— зауваження про роботу локомотивних приладів безпеки, комплексного локального пристрою безпеки;

— інформацію про швидкість руху поїзда перед сходом з рейок;

— інформацію про наявність від колії поштовхів під час руху;

— зауваження про стан контактної мережі;

— зауваження про роботу світлофорів.

Крім цього, комісією отримується письмова інформація про прямування поїзда від машиністів зустрічних поїздів, поїзного диспетчера, чергових по станціях напряму прямування поїзда, чергових по переїзду. 
12. У машиніста перевіряється наявність:

— посвідчення на право управління локомотивом;

- висновку машиніста-інструктора на право роботи на дільниці, де стався схід;

- службового формуляра та зауважень машиніста-інструктора стосовно виконання машиністом посадових обов'язків у поїзній і маневровій роботі, проаналізувати ці зауваження щодо відношення їх до сходу.

13. Після розшифрування швидкостемірної стрічки локомотива порівняти письмові пояснення локомотивної бригади 3 даними розшифрування швидкостемірної стрічки локомотива. Розшифрування швидкостемірної стрічки виконати для всього шляху прямування поїзда (від початкової станції відправлення до місця сходу). Начальник локомотивного, моторвагонного депо надає довідку про час роботи локомотивної бригади за останні 2 тижні та час відпочинку перед поїздкою.

14. Перевіряється технічний стан локомотива (моторвагонного рухомого складу) без сходження його з рейок. Якщо локомотив не сходив з рейок, то необхідно організувати перевірку його технічного стану на відповідність вимогам ПТЕ та іншим нормативно-правовим актам. Особливу увагу звернути на стан гальмівного обладнання, роботу гальм і пристрою для вимірювання швидкості руху (швидкостеміра). У разі катастроф та аварій проводиться обов'язкова перевірка справності цього пристрою (швидкостеміра) на стенді, про що складається відповідний акт.

15. Перевірити стан локомотива (МВРС) у разі сходу його з рейок. Результати огляду повинні бути оформленні актом (актами), підписаним посадовими особами та членами комісії, які проводили огляд локомотива та ревізорами залізниці чи дільниці залізниці, які контролюють проведення розслідування.

16. Перевірити технічний стан вагонів після сходу їх із рейок. Визначити відповідність зазначених параметрів вимогам нормативно-правових актів. При сході пасажирських вагонів додатково необхідно провести перевірку технічного стану вагонів на відповідність їх вимогам нормативних документів у період експлуатації, згідно з вимогами Інструкції оглядачу вагонів. Від працівників ПТО, на якому виконувалась підготовка поїзда до відправлення, необхідно отримати письмові пояснення, у яких повинні бути надані конкретні відповіді на питання, що стосуються огляду вагонів, випробування гальм, усунення виявлених несправностей при підготовці поїзда до відправлення й оформлення довідки за формою ВУ-45.

17. Перевірити технічний стан колії: план лінії, профіль лінії, конструкцію залізничної лінії, конструкцію верхньої будови колії і її стан, стан шпал та ін.

18. Отримати дані від керівників господарства перевезень:

- станція формування та станція відправлення поїзда;

- станція навантаження (вивантаження) вагона (вагонів), що зійшов;

- схема формування поїзда та відповідність цієї схеми пунктам ПТЕ, іншим нормативним документам і натурному листу форми ДУ-1; 
— кількість затриманих поїздів і загальний час їх простою;

- копія переліку недоліків, виявлених на стрілочному переводі, станційній колії при проведенні комісійних місячних оглядів (за останні 3 місяці, якщо схід стався на стрілочному переводі чи станційній колії).

19. Отримати дані, які готуються та надаються керівниками й фахівцями господарства комерційної роботи та маркетингу:

- схем розміщення й кріплення вантажів на рухомому складі, що зійшов 3 рейок;

— про наявність чи відсутність вагонів із перевантаженням понад установлені норми (вагонів, що зійшли, та вагонів, що прямували перед ними); колію.

- про відсутність чи наявність розвалювання вантажу і його падіння на

20. Отримати від керівників і фахівців господарства електропостачання дані про наявність та величину напруги в контактній мережі в момент сходу 3 рейок (якщо схід стався на електрифікованій дільниці), про стан тягового електропостачання перед сходом, після сходу та причини порушення нормальної його роботи (якщо такі порушення мали місце).

21. Отримати дані, які надаються керівниками господарства сигналізації та зв'язку:

- довідка про стан усіх систем СЦБ на перегоні, де стався схід;

- дані за показниками засобів контролю за рухом поїзда (ДИСК, ПОНАБ, КТСМ).

22. При сході на станції старший електромеханік разом із начальником станції складають акт про стан елементів управління пристроями СЦБ (кнопок, стрілочних комутаторів, пломб тощо).

Наведений перелік не вичерпує всіх обставин, які залежно від місцевих умов можуть характеризувати причину сходу, але достатньо обгрунтовано дозволить відповісти на питання стосовно його причини. Залежно від конкретних умов і обставин сходу рухомого складу перелік питань, що рекомендується, може бути скорочений або доповнений іншими.

У процесі розслідування зазначені матеріали повинні бути зібрані в окрему справу. Терміни проведення с. р. ЗТП і складання актів форми РБУ визначені в Тимчасовому порядку.

У разі неявної причини сходу або виникнення труднощів у збиранні інформації голова комісії може письмово звернутися до керівництва залізниці чи Укрзалізниці за дозволом щодо продовження термінів розслідування. При невизначенні причини сходу рухомого складу з рейок начальник залізниці може звернутися до комісії незалежних експертів. Після закінчення с. р., установлення причин на місці транспортної події складається відповідний акт форми РБУ та Технічний висновок про причини ЗТП за підписом голови та членів комісії, які проводили с. p. Матеріали розслідування розглядаються начальником залізниці. Кожен член комісії, який повинен підписати акт, але має зауваження, підписує його, зробивши відповідний запис (про незгоду).

Необхідно також зазначити, що в Методичних вказівках використані результати досліджень, проведених у Росії, Україні та інших країнах світу, 
а також багаторічний досвід фахівців Укрзалізниці з безпеки руху, накопичений при розслідуванні ЗТП.

Методологічні підходи до проведення службового розслідування залізнично-транспортних пригод за кордоном. Порядок і організація проведення сумісної роботи в рамках службового розслідування при порушенні безпеки руху в поїзній та маневровій роботі в країнах СНД $i$ Балтії затверджено в Інструкції про порядок спільних дій залізничних адміністрацій державучасників Співдружності Незалежних Держав Грузії, Латвійської Республіки, Литовської Республіки, Естонської Республіки зі службового розслідування порушень безпеки руху в поїзній і маневровій роботі (затверджена на п’ятдесятому засіданні Ради із залізничного транспорту 22 травня 2009 р., зі змінами та доповненнями станом на 22.10.2014). У цій Інструкції зазначений чіткий перелік порушень безпеки руху, при якому проводиться сумісне розслідування, порядок інформування про такі випадки, порядок самого розслідування і розгляд результату проведеного розслідування. Службове розслідування порушень безпеки руху виконується відповідно до цієї Інструкції та внутрішньодержавного законодавства, нормативних актів і процедур, які діють на території залізничної адміністрації, де виникла ЗТП.

Якщо розглянути окремо Республіку Казахстан, то Правила службового розслідування, обліку пожеж і їх наслідків на залізничному транспорті Республіки Казахстан були затверджені 1 травня 2004 р. № 101-I, що встановлювали порядок проведення службового розслідування, обліку пожеж і виплати збитків, спричинених пожежею здоров'ю працівників, громадян, майну і виробничим об'єктам організації залізничного транспорту. У Республіці Казахстан проводиться робота в напрямі підвищення рівня знань спеціалістів і покращення методики проведення с. р. Міністерством навчання та науки Республіки Казахстан у 2008 р. був затверджений і виданий навчальний посібник «Методика службового розслідування подій на залізничному транспорті» (Іваницький Р. П., 2008), у якому відображено загальну методику проведення с. p. на залізничному транспорті та декілька важливих моментів, таких як: підготовка та призначення залізничної технічної експертизи; порядок розслідування порушень правил безпеки руху, що призвели до зіткнення поїздів; порядок розслідування порушень правил безпеки руху, що призвели до сходу з рейок; порядок виявлення та виправлення обставин, що сприяють виникненню ЗТП; приклади проведення службових розслідувань та експертиз за фактами пригод на залізничних дорогах Республіки Казахстан. Також у 2011 р. був виданий навчальний підручник «Правила техничної експлуатації й основи безпеки руху на залізничному транспорті», у якому відображено елементи проведення с. р. катастроф і аварій, а саме: які основні документи необхідні для проведення с. р.; класифікація випадків порушень безпеки руху; безпосередньо порядок проведення с. р.; оформлення й розгляд результатів с. p.

У Росії до 1994 р. діяла Інструкція про порядок службового розслідування й обліку на залізничному транспорті нещасних випадків з людьми, не пов'язаних з виробництвом, затверджена МШС СРСР 31 грудня 1984 р. № ЦУО-4260 і вказівка від 25.12.1987 № Г-6613у. 
Із 1994 р. діяла Інструкція про порядок службового розслідування й обліку на залізничному транспорті нещасних випадків з людьми, не пов'язаних 3 виробництвом від 08.08.1994, яка встановлює порядок службового розслідування і обліку нещасних випадків з людьми на залізничному транспорті (у тому числі й із залізничниками), не зв'язаних з виробництвом, а також обов'язки працівників і посадових осіб відповідних управлінь і відділів залізниці, підприємств, організацій і закладів залізничного транспорту, що відповідають за проведення цієї роботи.

У 2006 р. було затверджено Положення про порядок службового розслідування й обліку транспортних подій та інших, пов'язаних з порушенням правил безпеки руху та експлуатації залізничного транспорту, подій. У це Положення включено загальні положення щодо службового розслідування ЗТП та інших подій, пов’язаних із порушенням правил безпеки руху та експлуатації залізничного транспорта, порядок оформлення результатів цього розслідування й звітність і їх облік.

Із зазначеного постає висновок, що методологічні підходи при проведенні с. p. ЗТП за кордоном і в Україні ще потребують певних змін. Сама ж робота в напрямі удосконалення цих підходів проводиться постійно, а це, безперечно, має своє позитивне відображення й на процесі дослідження в межах виконання судових залізнично-транспортних експертиз.

\section{МЕТОДОЛОГИЧЕСКИЕ ПОДХОДЫ К ПРОВЕДЕНИЮ СЛУЖЕБНОГО РАССЛЕДОВАНИЯ ЖЕЛЕЗНОДОРОЖНОГО ПРОИСШЕСТВИЯ В УКРАИНЕ И ЗА РУБЕЖОМ}

\section{Джус О. В.}

При перевозке железнодорожным транспортом пассажиров и грузов всегда присутствует риск появления нестандартной ситуации в результате воздействия различных факторов или действий людей (операторов) - железнодорожно-транспортного происшествия. При возникновении же такой ситуаџии проводятся служебные (специальные) расследования - устанавливаются причины ее наступления. Материаль, показания и факты, устанавливаемые при таком виде расследований, являются достаточно важными и используются при проведении исследования в рамках выполнения железнодорожно-транспортной экспертизы. Все усилия по усовершенствованию методов исследования причин и факторов влияния на возникновение железнодорожно-транспортных происшествий сводятся к одной цели повышение качества их расследования и предотвращение аварий и катастроф на железнодорожном транспорте в будущем. Существуют определенные методологические подходы при проведении служебного расследования железнодорожнотранспортных происшествий за рубежсм (в государствах Балтии, Казахстане, России) и в Украине. Подробно рассмотрен процесс проведения служебного расследования в Украине в соответствии с действующиии Методическими указанияли. Работа в направлении улучшения и совершенствования этих подходов проводится постоянно, и это, бесспорно, имеет свое положительное отражение и на прочессе исследования в рамках выполнения судебных железнодорожно-транспортных экспертиз. Также необходимо отметить, что грамотное, полное и качественное оформление материалов, представляемых судебным экспертам для выполнения 
экспертизы, позволит в оптимальные сроки выполнить назначенные судебные железнодорожно-транспортные экспертизы и предоставить обоснованные выводы.

Ключевые слова: железнодорожно-транспортное происшествие, катастрофа, авария, безопасность движения, служебное расследование, железнодорожно-транспортная экспертиза.

\section{METHODOLOGICAL APPROACHES TO CARRYING OUT THE OFFICIAL INVESTIGATION OF THE RAILWAY ACCIDENT IN UKRAINE AND ABROAD}

\section{Dzhus O. V.}

While transporting passengers and cargo by rail transport, there is always a risk of an unusual situation arising as a result of exposure to various factors or actions of people (operators) namely a railway transport accident. In case of such a situation official (special) investigations are performed; the reasons for its occurrence are detected. Materials, testimonies and facts determinated while performing this type of investigation are important enough and used while carrying out the research in the framework of railway transport forensic examination. All efforts to improve the methods of investigating the causes and factors of influence on the occurrence of railway transport accidents are reduced to one goal: improving the quality of their investigation and preventing crashes and catastrophes in rail transport in the future. There are certain methodological approaches while conducting an official investigation of railway transport accidents abroad (in the Baltic States, Kazakhstan, Russia) and in Ukraine. The process of performing an official investigation in Ukraine is examined in detail according to current Methodological Guidelines. Work towards improving and perfection these approaches has been ongoing and this has undoubtedly been positively reflected on the research process within the frameworks of implementation of forensic railway transport examinations. It should be also noted that the competent, complete and high-quality execution of materials submitted to forensic experts for performing examination will allow to fulfill the assigned forensic railway transport examinations and provide substantiated conclusions in optimal time frame.

Keywords: railway transport accident, catastrophe, crash, traffic safety, official investigation, railway transport examination.

DOI: https://doi.org/10.32353/khrife.2018.50

УДК 343.148.6:629.4.017

A. B. Батіг, старший науковий співробітник Львівського НДІСЕ, магістр

E-mail: batigasha1992@gmail.com

\section{АНАЛІТИЧНЕ ВИЗНАЧЕННЯ КРИТЕРІЇВ БЕЗПЕКИ РУХУ НА ЗАЛІЗНИЧНОМУ ТРАНСПОРТІ}

Виконано перевірку умов стійкості від сходу з рейок рухомого складу за прийнятими нормами для вагона моделі 11-286. Наведено основні недоліки використаного методу розрахунку та способи його вдосконалення.

Ключові слова: схід з рейок рухомого складу, катастрофа, аварія, безпека руху, стійкість від сходу з рейок. 